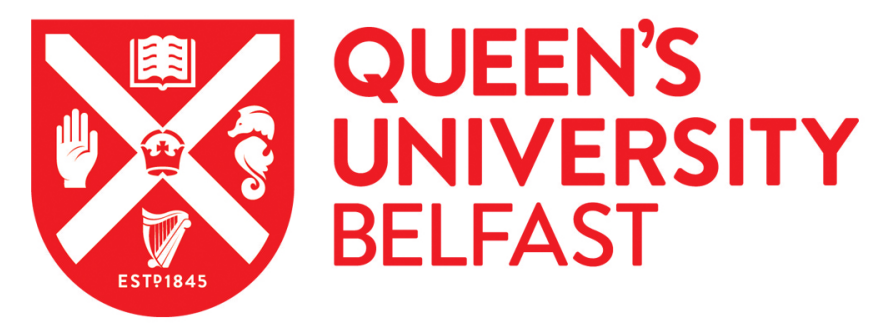

\title{
Protein Z plasma levels are not associated with the risk of coronary heart disease the PRIME Study
}

Morange, P. E., Juhan Vague, I., \& Evans, A. (2004). Protein Z plasma levels are not associated with the risk of coronary heart disease the PRIME Study. Journal of Thrombosis and Haemostasis, 2(11), 2050-2051.

Published in:

Journal of Thrombosis and Haemostasis

Queen's University Belfast - Research Portal:

Link to publication record in Queen's University Belfast Research Portal

\section{General rights}

Copyright for the publications made accessible via the Queen's University Belfast Research Portal is retained by the author(s) and / or other copyright owners and it is a condition of accessing these publications that users recognise and abide by the legal requirements associated with these rights.

Take down policy

The Research Portal is Queen's institutional repository that provides access to Queen's research output. Every effort has been made to ensure that content in the Research Portal does not infringe any person's rights, or applicable UK laws. If you discover content in the Research Portal that you believe breaches copyright or violates any law, please contact openaccess@qub.ac.uk. 
models: a mechanism of reduced vascular risk by moderate wine consumption. Ann NY Acad Sci 2002; 957: 174-88.

2 Di Castelnuovo A, Rotondo S, Iacoviello L, Donati MB, de Gaetano G. Meta-analysis of wine and beer consumption in relation to vascular risk. Circulation 2001; 18: 2836-44.

3 Revilla E, Ryan JM. Analysis of several phenolic compounds with potential antioxidant properties in grape extracts and wines by highperformance liquid chromatography-photodiode array detection without sample preparation. J Chromatgr A 2000; 881: 461-9.
4 Wollny T, Aiello L, Di Tommaso D, Bellavia V, Rotilio D, Donati MB, de Gaetano G, Iacoviello L. Modulation of haemostatic function and prevention of experimental thrombosis by red wine in rats: a role for increased nitric oxide production. Br J Pharmacol 1999; 127: 747-55.

5 De Curtis A, D'Adamo MC, Amore C, Polishchuck R, Di Castelnuovo A, Donati MB, Iacoviello L. Experimental arterial thrombosis in genetically or diet induced hyperlipidemia in rats: role of vitamin K-dependent clotting factors and prevention by low-intensity oral anticoagulation. Thromb Haemost 2001; 86: 1440-8.

\title{
Protein $\mathrm{Z}$ plasma levels are not associated with the risk of coronary heart disease: the PRIME Study
}

\author{
P. E. MORANGE and I. JUHAN-VAGUE* ON BEHALF OF THE PRIME STUDY GROUP \\ ${ }^{*}$ Hematology Laboratory, CHU Timone, Inserm U626, Faculty of medicine, Marseille
}

To cite this article: Morange PE, Juhan-Vague I on behalf of the PRIME Study Group. Protein Z plasma levels are not associated with the risk of coronary heart disease: the PRIME Study. J Thromb Haemost 2004; 2: 2050-1.

Protein Z, a vitamin K-dependent plasma glycoprotein, is thought to play a role in coagulation by serving as a cofactor to increase the inhibition of factor $(\mathrm{F}) \mathrm{Xa}$ by a protein Z-dependent protease inhibitor by more than 1000 times $[1,2]$. Both in vitro and mice studies led to speculation that protein $\mathrm{Z}$ deficiency could be a risk factor for thrombosis in humans $[1,3]$. However, epidemiological data on the role of protein $\mathrm{Z}$ are based on retrospective studies and provide conflicting results [4-10]. We aimed to determine whether plasma levels of protein $\mathrm{Z}$ could influence the risk of coronary disease using the Prospective Epidemiological Study of Myocardial Infarction (PRIME) prospective cohort. The design of this nested case-control study was extensively reported elsewhere $[11,12]$. The PRIME Study was initially designed to explain the several-fold differences in risk of coronary heart disease between France and Northern Ireland. Briefly, over 10000 apparently healthy men recruited in France (Lille, Strasbourg, Toulouse) and Northern Ireland (Belfast) were included in the study. The risk of future coronary events was almost two times higher in Northern Ireland than in France, this difference being not adequately explained by conventional cardiovascular risk factors [11,12]. We measured baseline plasma concentration of protein Z antigen among 297 participants who subsequently developed coronary events and in 593 age-matched controls who remained free of disease over the 5 years of follow-up. Determination of protein $\mathrm{Z}$ was

Correspondence: I. Juhan-Vague, Hematology Laboratory, CHU Timone-13385, Marseille cedex 5, France.

Tel.: +33 4 91386049; fax: +33 4 91254336; e-mail: ijuhan@ap-hm.fr

Received 30 April 2004, accepted 15 July 2004 performed with a commercially available ELISA (Asserachrom Protein Z Diagnostica Stago, Asnière, France), following the manufacturer's instruction. The interassay coefficient of variation was $7.1 \%$.

Plasma protein $\mathrm{Z}$ was not associated with any of the conventional cardiovascular risk factors [hypertension, smoking status, diabetes, body mass index, total cholesterol, highdensity lipoprotein cholesterol and C-reactive protein (CRP), data not shown]. Baseline concentrations of protein $\mathrm{Z}$ were not significantly different between individuals who experienced a coronary event during follow-up and those who did not, either in the whole cohort or when considering each country separately (Table 1). Protein $\mathrm{Z}$ concentrations were similar among individuals with myocardial infarction or coronary death and those with angina pectoris (mean \pm SEM: $1.56 \pm 0.05$ vs. $1.61 \pm 0.05 \mathrm{mg} \mathrm{L}^{-1}$, respectively; $P=0.29$ ). Plasma protein $\mathrm{Z}$ levels were higher in Northern Ireland than in

Table 1 Means (SEM) of plasma protein $Z$ in cases and controls and relative risk of coronary event associated with $1 \mathrm{SD}$ increase of protein $\mathrm{Z}$ level

\begin{tabular}{lllll}
\hline & $\begin{array}{l}\text { Controls } \\
\text { (France/ } \\
\text { N. Ireland; } \\
n=344 / 249)\end{array}$ & $\begin{array}{l}\text { Cases } \\
\text { (France/ } \\
\text { N. Ireland; } \\
n=172 / 125)\end{array}$ & $P^{*}$ & $\begin{array}{l}\text { Relative } \\
\text { risk (95\% } \\
\text { confidence } \\
\text { interval) }\end{array}$ \\
\hline $\begin{array}{l}\text { All } \dagger \\
\text { France }\end{array}$ & $1.64(0.03)$ & $1.58(0.04)$ & 0.17 & $0.90[0.78-1.05]$ \\
$\begin{array}{l}\text { Northern } \\
\text { Ireland }\end{array}$ & $1.58(0.03)$ & $1.57(0.05)$ & 0.65 & $0.95[0.78-1.17]$ \\
$P^{* *}$ & $1.72(0.04)$ & $1.61(0.06)$ & 0.13 & $0.84[0.64-1.05]$ \\
\hline
\end{tabular}

Values are in $\mathrm{mg} \mathrm{L}^{-1}$. ${ }^{*} P$ for difference between cases and controls are derived from conditional logistic regression. ${ }^{* *} P$ for difference between France and Northern Ireland. $†$ Means and relative risk are adjusted for population. 
France (mean \pm SEM: $1.68 \pm 0.03$ vs. $1.58 \pm 0.03 \mathrm{mg} \mathrm{L}^{-1}$; $P=0.01)$. This difference appeared stronger in controls than in cases (Table 1), even though the interaction did not reach significance $(P=0.38)$.

As two studies have suggested a threshold effect in which low levels of protein $\mathrm{Z}$ increased the risk of thrombosis $[4,6]$, we have stratified the population into two groups according to the 10th percentile of the distribution in controls. In the whole cohort, 10 percent $(n=58)$ of healthy controls had protein $\mathrm{Z}$ levels below $0.93 \mathrm{mg} \mathrm{L}^{-1}$ (10th percentile $=0.93 \mathrm{mg} \mathrm{L}^{-1}$ ). Eleven percent $(n=32)$ of the patients had protein $\mathrm{Z}$ levels below this cut-off $(P=0.58)$, which means that protein $\mathrm{Z}$ below $0.93 \mathrm{mg} \mathrm{L}^{-1}$ was not a risk factor for coronary disease. This was homogeneous across countries as $12 \%(n=21)$ and $10 \%(n=12)$ of the patients, in France and Northern Ireland, respectively, had protein $\mathrm{Z}$ levels below the 10th percentile which was set in controls for each country separately $(P=0.47$ and 0.80 for case-control difference in France and Northern Ireland, respectively).

In conclusion, antigenic protein $\mathrm{Z}$ levels do not seem to have a major effect on the risk of coronary heart disease in healthy men followed for 5 years.

\section{References}

1 Broze GJ Jr. Protein Z-dependent regulation of coagulation. Thromb Haemost 2001; 86: 8-13.

2 Han X, Fiehler R, Broze GJ Jr. Characterization of the protein Z-dependent protease inhibitor. Blood 2000; 96: 3049-55.
3 Yin ZF, Huang ZF, Cui J, Fiehler R, Lasky N, Ginsburg D, Broze GJ Jr. Prothrombotic phenotype of protein $\mathrm{Z}$ deficiency. Proc Natl Acad Sci USA 2000; 97: 6734-8.

4 Vasse M, Guegan-Massardier E, Borg JY, Woimant F, Soria C. Frequency of protein $\mathrm{Z}$ deficiency in patients with ischaemic stroke. Lancet 2001; 357: 933-4.

5 Kobelt K, Demarmels Biasiutti F, Mattle HP, Lammle B, Wuillemin WA. Protein Z in ischaemic stroke. Br J Haematol 2001; 114: 169-73.

6 Heeb MJ, Paganini-Hill A, Griffin JH, Fisher M. Low protein Z levels and risk of ischemic stroke: differences by diabetic status and gender. Blood Cells Mol Dis 2002; 29: 139-44.

7 Lopaciuk S, Bykowska K, Kwiecinski H, Czlonkowska A, Kuczynska-Zardzewialy A. Protein $\mathrm{Z}$ in young survivors of ischemic stroke. Thromb Haemost 2002; 88: 536.

8 Fedi S, Sofi F, Brogi D, Tellini I, Cesari F, Sestini I, Gazzini A, Comeglio M, Abbate R, Gensini GF. Low protein Z plasma levels are independently associated with acute coronary syndromes. Thromb Haemost 2003; 90: 1173-8.

9 McQuillan AM, Eikelboom JW, Hankey GJ, Baker R, Thom J, Staton J, Yi Q, Cole V. Protein Z in ischemic stroke and its etiologic subtypes. Stroke 2003; 34: 2415-9.

10 Lichy C, Kropp S, Dong-Si T, Genius J, Dolan T, Hampe T, Stoll F, Reuner K, Grond-Ginsbach C, Grau A. A common polymorphism of the protein $\mathrm{Z}$ gene is associated with protein $\mathrm{Z}$ plasma levels and with risk of cerebral ischemia in the young. Stroke 2004; 35: 40-5.

11 Yarnell JW. The PRIME study: classical risk factors do not explain the severalfold differences in risk of coronary heart disease between France and Northern Ireland: Prospective Epidemiological Study of Myocardial Infarction. Quart J Med 1998; 91: 667-76.

12 Ducimetiere P, Ruidavets JB, Montaye M, Haas B, Yarnell J. Fiveyear incidence of angina pectoris and other forms of coronary heart disease in healthy men aged 50-59 in France and Northern Ireland: the Prospective Epidemiological Study of Myocardial Infarction (PRIME) Study. Int J Epidemiol 2001; 30: 1057-62.

\title{
Aspirin resistance in vitro and hypertension in stroke patients
}

\author{
L. MACCHI, * E.PETIT, †A.BRIZARD, ${ }^{*}$ R. GIL† and J.P. NEAU $\dagger$ \\ *Laboratoire d'Hématologie et des maladies du sang. Service de neurologie, †Hôpital La Miletrie, CHU Poitiers, Poitiers, France
}

To cite this article: Macchi L, Petit E, Brizard A, Gil R, Neau JP. Aspirin resistance in vitro and hypertension in stroke patients. J Thromb Haemost 2004; 2: 2051-3.

See also Smith JB, Mustard JF, Jilma B, Fuchs I, Violi F, Pignatelli P, Pulcinelli FM, De Gaetano G, Cerletti C; Rosenson RS, Wolff D, Green D, Boss $\mathrm{AH}$, Kensey KR. Forum on aspirin. J Thromb Haemost 2004; 2: 335-41; Patrono C. Aspirin resistance: definition, mechanisms and clinical read-outs. J Thromb Haemost 2003; 1: 1710-13.

Aspirin reduces the relative risk for cerebral events in patients with cardiovascular or cerebrovascular disorders by approximately $23 \%$ [1]. Despite its large use, there are concerns about

Correspondence: L. Macchi, Laboratoire d'Hématologie et des maladies du sang Hôpital La Miletrie, CHU Poitiers, Poitiers, France. Tel.: + 335 49444682; fax: + 335 49444095; e-mail: 1.macchi@, chu-poitiers.fr

Received 17 June 2004, accepted 24 June 2004 the efficacy of aspirin and methods to evaluate it [2,3]. Indeed, it appears that the antiplatelet effect of aspirin is not uniform in all patients and previous studies estimated that $8-45 \%$ of the population were aspirin resistant [4-8]. Most studies have focused on patients with coronary artery disease, although a few reports have identified aspirin resistance in patients with stroke or cerebrovascular disease [6-9]. In this study we evaluated aspirin resistance in vitro using the PFA- $100^{\circledR}$ method, in 37 patients ( 20 women and 17 male; mean age $=$ $60 \pm 14.7$ years) treated with aspirin $160 \mathrm{mg} \mathrm{d}^{-1}$ for secondary prevention of stroke ( 28 cerebral infarcts, nine transient 